\title{
The Risk Factors toward Preeclampsia Events of Pregnant Women in Meureubo and Johan Pahlawan Community Health Center West Aceh
}

\author{
Yushida Yushida*, Evi Zahara
}

Department of Midwifery, Ministry of Health, Polytechnic of Meulaboh, Aceh, Indonesia

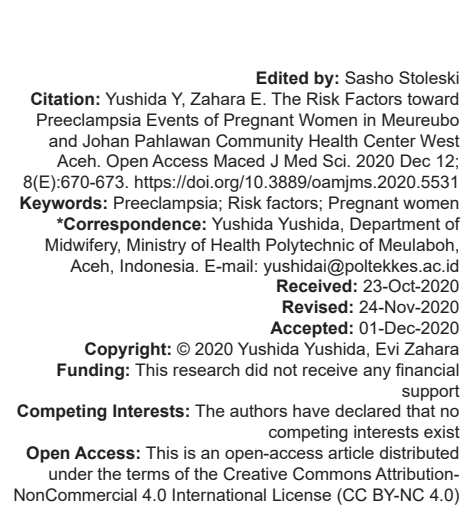

\section{Introduction}

Forty percent of pregnant women experience labor complications during delivery [1]. A recent report from the World Health Organization estimates that preeclampsia is directly responsible for 70,000 maternal deaths worldwide [2]. In addition to maternal mortality and morbidity, preeclampsia also causes 500,000 infant deaths annually [3]. Preeclampsia is one of the leading causes of maternal death, which results in estimated 50,000-60,000 deaths every year worldwide. The incidence of preeclampsia in developing countries is about seven times higher than in developed countries (average $2.8 \%$ of live births vs. $0.4 \%$ ) [4], [5]. Maternal mortality due to preeclampsia is increasing every year in Indonesia.

Preeclampsia in pregnancy can have adverse effects on both the mother and the fetus. Preeclampsia provides a higher risk of death from cardiovascular, kidney, liver, and other diseases [6]. The maternal mortality rate in Indonesia is one measure of the quality of midwifery services and an essential public health indicator. Preeclampsia is a common pregnancy condition characterized by the onset of hypertension and proteinuria [7]. Many factors can increase the risk of preeclampsia in pregnancy. Prevention of preeclampsia can be done by identifying risk factors and closely monitoring women at risk to hope that the preeclampsia rate can be reduced. Preeclampsia is becoming an increasingly common diagnosis in developed countries and remains a significant cause of maternal and fetal morbidity and mortality in developing countries [8]. The 2019 National Institute for Health and Care Excellence guidelines classify a woman at high risk of preeclampsia if there is a history of hypertensive disease during a previous pregnancy or maternal disease, kidney disease, autoimmune disease, diabetes, or chronic hypertension [9].

Identifying predisposing factors in prepregnancy and early pregnancy stages will help reduce morbidity and mortality [10]. The prevalence of preeclampsia cases in the province of Aceh has increased every year. Based on reports from the Health Office of West Aceh District in 2013, 33\% of preeclampsia is the leading cause of maternal mortality 
in West Aceh District. The preeclampsia incidence of being prevented by providing advice on dietary food, adequate rest, antenatal surveillance [11]. The general objective of the study was to analyze to determine the effect of risk factors on the incidence of preeclampsia in pregnant women in the working areas of the Meureubo and Johan Pahlawan Public health center, Aceh Barat District.

\section{Methods}

This study used an analytic observational research approach with a case-control design. The case-control design is an observational analytic epidemiological study that examines the relationship between the effect (disease or health condition) of a particular risk factor. The case population in this study was all pregnant women diagnosed with preeclampsia who were treated in the working area of the Meureubo and Johanahlawan Public health center, Aceh Barat District. In this study, the sample of cases were some pregnant women who suffered from preeclampsia recorded in medical records in the Work Area of the Meureubo and Johan Pahlawan Public health center, West Aceh Regency for the period January 1September 30, 2019, namely 80 cases. The sampling technique used in this study was Simple Random Sampling, where each sample from several sample populations may have the same opportunity to be selected. The number of samples was 31 cases and 21 controls with a ratio of 1:1 - data processing using univariate, bivariate analysis with Chi-square test, and multivariate analysis with multiple logistic regression.

\section{Results}

From Table 1, it is known that the largest group of cases was $\leq 35$ years old, 11 people (52.4\%), while the largest control group was $\leq 35$ years old, 17 people $(81.0 \%)$. The bivariate analysis results showed no significant relationship between age and preeclampsia incidence in pregnant women with a $p=0.102>0.05$. In the aspect of knowledge, a significant relationship between knowledge factor and incidence of preeclampsia with a $p=0.029<0.05$. The analysis results obtained an odds ratio $(\mathrm{OR})=0.171$, which means that pregnant women who have poor knowledge have a 0.171 risk of getting preeclampsia. There was no significant relationship between the parity factor and the incidence of preeclampsia in the parity variable. $p=0.07>0.05$. In the food consumption variable, there is no significant relationship between the consumption of fibrous food
Table 1: Distribution of factors associated with the incidence of preeclampsia in pregnant women

\begin{tabular}{|c|c|c|c|c|c|c|c|c|}
\hline \multirow[t]{2}{*}{ Variable } & \multicolumn{2}{|c|}{ Case } & \multicolumn{2}{|c|}{ Control } & \multicolumn{2}{|c|}{ Total } & \multirow[t]{2}{*}{$p$-value } & \multirow[t]{2}{*}{ OR (Cl 95\%) } \\
\hline & $\mathrm{n}$ & $\%$ & $\mathrm{n}$ & $\%$ & $\mathrm{n}$ & $\%$ & & \\
\hline \multicolumn{9}{|l|}{ Age } \\
\hline$\leq 35$ years & 1 & 2.4 & 17 & 1.0 & 28 & 66.7 & \multirow[t]{3}{*}{0.102} & \multirow[t]{3}{*}{$3.864(0.9-15.4)$} \\
\hline$>35$ years & 10 & 47.6 & 4 & 19.0 & 14 & 33.3 & & \\
\hline Total & 21 & 100 & 21 & 100 & 42 & 100 & & \\
\hline \multicolumn{9}{|l|}{ Knowledge } \\
\hline Good & 8 & 38.1 & 16 & 76.2 & 24 & 47.6 & \multirow[t]{3}{*}{0.07} & \multirow[t]{3}{*}{$0.171(0.031-0.939)$} \\
\hline Not good & 3 & 61.9 & 5 & 23.8 & 18 & 52.4 & & \\
\hline Total & 1 & 100 & 21 & 100 & 42 & 100 & & \\
\hline \multicolumn{9}{|l|}{ Parietals } \\
\hline Primigravida & 2 & 9.5 & 8 & 38.1 & 10 & 23.8 & \multirow[t]{3}{*}{0.27} & \multirow[t]{3}{*}{$0.33(0.07-1.52)$} \\
\hline Multigravida & 19 & 90.5 & 13 & 61.9 & 32 & 76.2 & & \\
\hline Total & 21 & 100 & 21 & 100 & 42 & 100 & & \\
\hline \multicolumn{9}{|l|}{ Heavy } \\
\hline Good & 14 & 66.7 & 18 & 85.7 & 32 & 76.2 & \multirow[t]{3}{*}{0.27} & \multirow[t]{3}{*}{$0.33(0.07-1.52)$} \\
\hline Not good & 7 & 33.3 & 3 & 14.3 & 10 & 23.8 & & \\
\hline Total & 21 & 100 & 21 & 100 & 42 & 100 & & \\
\hline \multicolumn{9}{|l|}{ Hypertension } \\
\hline No & 14 & 66.7 & 21 & 100 & 35 & 83.3 & \multirow[t]{3}{*}{0.009} & \multirow[t]{3}{*}{$2.50(0.267-0.600)$} \\
\hline Yes & 7 & 33.3 & 0 & 0 & 7 & 16.7 & & \\
\hline Total & 21 & 100 & 21 & 100 & 42 & 100 & & \\
\hline \multicolumn{9}{|l|}{ DM } \\
\hline No & 19 & 90.5 & 21 & 100 & 40 & 95.2 & \multirow[t]{3}{*}{0.48} & \multirow[t]{3}{*}{$0.47(0.343-0.658)$} \\
\hline Yes & 2 & 9.5 & 0 & 0 & 2 & 4.8 & & \\
\hline Total & 21 & 100 & 21 & 100 & 42 & 100 & & \\
\hline
\end{tabular}

factors on the incidence of preeclampsia in pregnant women with a $p=0.27>0.05$. In the hypertension variable, there is a significant relationship between hypertension factors and the incidence of preeclampsia in pregnant women with a $p=0.009<0.05$. The analysis results obtained an $\mathrm{OR}=2.50$, which means that pregnant women who have a history of hypertension have a 2.50 times risk of developing preeclampsia compared to pregnant women who do not have a history of hypertension. In the DM variable, there is no significant relationship between DM factors and the incidence of preeclampsia in pregnant women with a $p=0.48>0.05$.

\section{Discussion}

Women with preeclampsia have an increased risk of future health complications [12], [13]. Various clinical studies in women with preeclampsia have shown an increased risk of developing cardiovascular disease later in life [14]. This disease is characterized by hypertension, edema, and proteinuria, sometimes accompanied by convulsions to coma, increasing maternal and fetal morbidity and mortality. Preeclampsia is the leading cause of maternal morbidity and mortality worldwide, complicating $2-8 \%$ of pregnancies [15]. The analysis results show that there is a significant relationship between knowledge and hypertension with the incidence of preeclampsia, while for the variables age, parity, food consumption, and history of DM do not have a significant relationship. The results of statistical tests show that the knowledge factor with a $p=0.005$ and chronic hypertension has a $p=0.009<0.05$, which means that it has a significant relationship with the incidence of preeclampsia in pregnant women in the working area of the Meureubo and Johan Pahlawan Community Health Center, West Aceh Regency. 
Most studies show that preeclampsia of releases with age [16], [17]. Age is related to the increase or decrease in body function so that it affects health status. Preeclampsia is more often found in the early and late reproductive years, namely adolescence or over 35 years. Pregnant women $<20$ years old easily experience an increase in blood pressure (BP) and cause seizures more quickly. Meanwhile, people over 35 years of age are prone to increase BP. The knowledge analysis results show that there is a significant relationship between knowledge and the incidence of preeclampsia in pregnant women in the working area of the Meureubo and Johan Pahlawan Community Health Center, West Aceh Regency. Poor knowledge that develops in society has the potential for preeclampsia. Gaps in knowledge about the causes, diagnosis, and treatment of preeclampsia may be due to a lack of refresher training and a lack of written practice guidelines on preeclampsia management [18]. There are maternal and clinical risk factors that contribute to the high risk of preeclampsia, such as genetic factors, diet, parity, gestational weight gain, maternal age, multiple pregnancies, and previous preeclampsia history. Preexisting maternal conditions such as diabetes, chronic hypertension, and infections) are thought to play an influential role in preeclampsia development [19], [20]. Risk factors for preeclampsia include first pregnancy, obesity, hypertension, older age, and DM [21]. Several additional clinical factors significantly increase the risk of preeclampsia, including an increase in mean arterial BP before 15 weeks of gestation, polycystic ovary syndrome, respiratory distress during sleep, and various infections periodontal [22], [23]. Besides, many epidemiological studies have shown that chronic kidney disease significantly increases preeclampsia risk [24]. Various efforts can be made to minimize preeclampsia risk in pregnant women, one of which is supremes. Vitamin D supplementation started at 10-18 weeks of pregnancy does not reduce preeclampsia [25]. Besides, early detection of the risk of preeclampsia is essential as early anticipation. Some developed countries in the world have reduced the incidence of preeclampsia and associated mortality by almost $90 \%$ by utilizing a combination of early detection during antenatal care and increasing access to hospital care for women with preeclampsia [26]. The anticipation of preeclampsia depends on the detection of risk factors, measurement of arterial pressure, proteinuria, and edema. The anticipation of women with preeclampsia lies in need of medical care and preventive measures that prolong pregnancy and reduce both mother and fetus [27].

\section{Conclusion}

The knowledge and hypertension factors significantly affect the incidence of preeclampsia in pregnant women at the Meureubo Community Health Center and Johan Pahlawan, West Aceh District. Variable age, parity, and food consumption significantly relate to the incidence of preeclampsia in pregnant women. The results of our calculations show that the OR value is 2.50 . This result means that pregnant women have been tested to have congenital illnesses such as hypertension, this mother has a risk of illness 2.50 times more experiencing preeclampsia than pregnant women who do not have a history of hypertension. The variables of age, parity, food consumption, and history of DM were not significantly associated with the incidence of preeclampsia in pregnant women with $p>0.05$.

\section{References}

1. Ronsmans C, Graham WJ; Lancet Maternal Survival Series Steering Group. Maternal mortality: Who, when, where, and why. Lancet. 2006;368(9542):1189-200. https://doi.org/10.1016/ s0140-6736(06)69380-x

PMid:17011946

2. Sibai B, Dekker G, Kupferminc M. Pre-eclampsia Lancet. 2005;365(9461):785-99. https://doi.org/10.1016/ s0140-6736(05)71003-5

PMid:15733721

3. Khan KS, Wojdyla D, Say L, Gülmezoglu AM, Van Look PF. WHO analysis of causes of maternal death: A systematic review. Lancet. 2006;367(9516):1066-74. https://doi.org/10.1016/ s0140-6736(06)68397-9

PMid:16581405

4. Kartika AR, Akbar MI, Umiastuti P. Risk factors for preeclampsia weight in Dr. Hospital. Soetomo Surabaya in 2015. Gynecol Obstetrics Magazine. 2017;25:6-9. https://doi.org/10.20473/ mog.v25i12017.6-9

5. Osungbade KO, Ige OK. Public health perspectives of preeclampsia in developing countries: Implication for health system strengthening. J Pregnancy. 2011;2011:481095. https:// doi.org/10.1155/2011/481095

PMid:21547090

6. Lisonkova S, Sabr Y, Mayer C, Young C, Skoll A, Joseph KS Maternal morbidity associated with early-onset and late-onset preeclampsia. Obstet Gynecol. 2014;124(4):771-81. https://doi. org/10.1097/aog.0000000000000472 PMid:25198279

7. English FA, Kenny LC, McCarthy FP. Risk factors and effective management of preeclampsia. Integr Blood Press Control. 2015;3(8):7-12. https://doi.org/10.2147/ibpc.s50641 PMid:25767405

8. Phipps E, Prasanna D, Brima W, Jim B. Preeclampsia: Updates in pathogenesis, definitions, and guidelines. Clin $\mathrm{J}$ Am Soc Nephrol. 2016;11(6):1102-13. https://doi.org/10.2215/ cjn.12081115

PMid:27094609

9. National Guideline Alliance (UK) Hypertension in Pregnancy: Diagnosis and Management (NG133); 2019.

10. Bej P, Chhabra P, Sharma AK, Guleria K. Determination of risk factors for pre-eclampsia and eclampsia in a tertiary hospital of India: A case control study. J Family Med Prim Care. 2013;2(4):371-5. https://doi.org/10.4103/2249-4863.123924 PMid:26664844 
11. National Institute for Health and Clinical. Manuaba, Ide Ayu Chandranita dkk, IImu Kebidanan, Penyakit Kandungan dan KB Untuk Pendidikan Bidan, EGC, Jakarta: National Institute for Health and Clinical; 2010.

12. Chen CW, Jaffe IZ, Karumanchi SA. Pre-eclampsia and cardiovascular disease. Cardiovasc Res. 2014;101(4):579-86. https://doi.org/10.1093/cvr/cvu018 PMid:24532051

13. Wang IK, Muo $\mathrm{CH}$, Chang YC, Liang $\mathrm{CC}$, Chang $\mathrm{CT}$, Lin SY, et al. Association between hypertensive disorders during pregnancy and end-stage renal disease: A population-based study. CMAJ. 2013;185(3):207-13. https://doi.org/10.1503/cmaj.120230 PMid:23339156

14. Ahmed R, Dunford J, Mehran R, Robson S, Kunadian V. Preeclampsia and future cardiovascular risk among women: A review. J Am Coll Cardiol. 2014;63(18):1815-22. https://doi. org/10.1016/j.jacc.2014.02.529 PMid:24613324

15. Duley L. The global impact of pre-eclampsia and eclampsia. Semin Perinatol. 2009;33(3):130-7. https://doi.org/10.1053/j. semperi.2009.02.010 PMid:19464502.

16. Bilano VL, Ota E, Ganchimeg T, Mori R, Souza JP. Risk factors of pre-eclampsia/eclampsia and its adverse outcomes in lowand middle-income countries: A WHO secondary analysis. PLoS One. 2014;9(3):e91198. https://doi.org/10.1371/journal. pone.0091198 PMid:24657964

17. Lee CJ, Hsieh TT, Chiu TH, Chen KC, Lo LM, Hung TH. Risk factors for pre-eclampsia in an Asian population. Int $\mathrm{J}$ Gynaecol Obstet. 2000;70(3):327-33. https://doi.org/10.1016/ s0020-7292(00)00240-x PMid: 10967166

18. Olaoye T, Oyerinde OO, Elebuji OJ, Ologun O. Knowledge, perception and management of pre-eclampsia among health care providers in a maternity hospital. Int $\mathrm{J} \mathrm{MCH}$ AIDS. 2019;8(2):80-8. https://doi.org/10.21106/ijma.275 PMid:31723478

19. Magnus P, Trogstad L. Research on pre-eclampsia in a Norwegian mother and child cohort study Norsk. Epidemiology.
2014;24:97-102. https://doi.org/10.5324/nje.v24i1-2.1808

20. Shiozaki A, Saito S. Preeclampsia: Basic, Genomic, and Clinical, Saito. Singapore: Risk Factors for Preeclampsia; 2018. p. 3-25. https://doi.org/10.1007/978-981-10-5891-2_1

21. Al-Jameil N, Khan FA, Khan MF, Tabassum H. A brief overview of preeclampsia. J Clin Med Res. 2014;6(1):1-7. https:// doi:10.4021/jocmr1682w

PMid:24400024

22. North RA, McCowan LM, Dekker GA, Poston L, Chan EH, Stewart AW, et al. Clinical risk prediction for pre-eclampsia in nulliparous women: Development of model in international prospective cohort. Version 2. BMJ. 2011;7:d1875. https://doi. org/10.1136/bmj.d1875

PMid:21474517

23. Yu HF, Chen HS, Rao DP, Gong J. Association between polycystic ovary syndrome and the risk of pregnancy complications: A PRISMA-compliant systematic review and meta-analysis. Medicine (Baltimore). 2016;95(51):e4863. https://doi.org/10.1097/md.0000000000004863 PMid:28002314

24. Clowse ME, Jamison M, Myers E, James AH. A national study of the complications of lupus in pregnancy. Am J Obstet Gynecol. 2008;199(2):127.e1-6. https://doi.10.1016/j.ajog.2008.03.012 PMid:18456233

25. Mirzakhani H, Litonjua AA, McElrath TF, O'Connor G, LeeParritz A, Iverson R, et al. Early pregnancy Vitamin D status and risk of preeclampsia. J Clin Invest. 2016;126(12):4702-15. https://doi.org/10.1172/jci89031

PMid:27841759

26. Kim YM, Ansari N, Kols A, Tappis H, Currie S, Zainullah P, et al. Prevention and management of severe pre-eclampsia/ eclampsia in Afghanistan. BMC Pregnancy Childbirth. 2013;13:186. https://doi.org/10.1186/1471-2393-13-186 PMid:24119329

27. Brown MC, Bell R, Collins C, Waring G, Robson SC, Waugh J, et al. Women's perception of future risk following pregnancies complicated by preeclampsia. Hypertens Pregnancy. 2013;32(1):60-73. https://doi.org/10.3109/10641955.2012.704108 PMid:22957520 